\title{
Study of developing scales for assessment of the levels of readiness and satisfaction of participants in e-learning environments
}

\author{
Yasemin GÜLBAHAR *
}

\begin{abstract}
Specification and consideration of students level of e-readiness before the process and levels of e-satisfaction after the process might lead to important findings regarding both the process and the product, and might result an increase in effectiveness and efficiency of e-Learning processes by producing of new approaches and strategies based on these findings. In the light of these facts, this study is conducted to develop two scales, namely "e-Readiness Scale" and "eSatisfaction Scale", and contribute to future studies by approving the reliability and validity of these instruments. Population for this study is composed of 3270 students who are enrolled in various distance education programs that delivers instruction via e-Learning approach in a state university. It can be concluded that results of analysis has met the expected criteria for goodness. It is another evidence that reliability coefficient for e-readiness scale ranged between .77-.80 whereas for esatisfaction survey the values were between .91-.96 which implies the reliability of the scales.
\end{abstract}

Keywords: e-Learning, e-readiness, e-satisfaction, scale.

"Assoc. Prof. Dr., Ankara University, Department of Informatics, Ankara, Turkey.

E-mail: gulbahar@ankara.edu.tr 


\section{SUMMARY}

Purpose and significance: Due to several obstacles in educational institutions in our country, like not having an updated and diffused infrastructure, no standardization in terms of technical competencies and capabilities for both instructors and students, it is hard to conduct research studies on this topic. Specification and consideration of students level of e-readiness before the process and levels of esatisfaction after the process might lead to reveal important findings regarding both the process and the product, and might result an increase in effectiveness and efficiency of e-Learning processes by producing of new approaches and strategies based on these findings. In the light of these facts, this study is conducted to develop two scales, namely "e-Readiness Scale" and "e-Satisfaction Scale", and contribute to future studies by approving the reliability and validity of these instruments.

Method: Population for this study is composed of 3270 students who are enrolled in various distance education programs that delivers instruction via e-Learning approach in a state university. Within the scope of this study, e-readiness scale was completed by 2963 students whereas e-satisfaction scale was completed by 2706 students. First, descriptive factor analysis has been made in order to discover factor structure based on relations between variables. After that, confirmatory factor analysis has been made to investigate model-data agreement and goodness of fit indexes has been explored in order to test validity.

Results: It is found that reliability coefficient for e-readiness scale ranged between .77-.80 whereas for e-satisfaction survey the values were between .91-.96 which implies the reliability of the scales. Moreover, both model-data agreement and the values of goodness of fit indexes were acceptable.

Discussion and Conclusions: It can be concluded that results of analysis has met the expected criteria for goodness. Hence, both scales can be used to measure their intended scopes. 


\title{
E-Öğrenme Ortamlarında Katılımcıların Hazır Bulunuşluk ve Memnuniyet Düzeylerinin Ölçülmesi için Ölçek Geliştirme Çalışması
}

\author{
Yasemin GÜLBAHAR *
}

ÖZ. Öğrencilerin süreç öncesinde e-Öğrenme sürecine ilişkin Hazır bulunuşluk düzeyleri ve süreç sonrasında memnuniyet düzeylerinin belirlenmesi ve dikkate alınması, hem sürece hem de sonuca ilişkin çok önemli bulgular ortaya çıkmasına ve bu bulgulara dayalı yeni yaklaşım ve stratejilerin üretilmesi ile e-Öğrenme sürecinde öğretimin etkiliğinin ve verimliliğinin artmasına katkı sağlayabilmektedir. $\mathrm{Bu}$ düşünceden hareket ile bu çalışma, "eÖğrenme Sürecine İlişkin Hazır Bulunuşluk ve Beklenti Ölçeği” ile "e-Öğrenme Sürecine İlişkin Memnuniyet Ölçeği”" olmak üzere iki ölçek geliştirmek, bu ölçeklerin geçerlik ve güvenirlik çalışmalarını yaparak gelecekte yapılacak çalışmalara katkı sağlayabilmek amacıyla gerçekleştirilmiştir. Araştırmanın evreni, bir devlet üniversitesinin eÖğrenme yöntemi ile eğitim-öğretim yapan farklı programlarına kayıtlı 3270 öğrenciden oluşmaktadır. Analiz sonuçlarının model-veri uyumu için belirtilen ölçütleri karşıladığı ifade edilebilir. Ölçek puanları için hesaplanan güvenirlik katsayılarının da genel olarak "eÖğrenme Sürecine İlişkin Hazır Bulunuşluk ve Beklenti Ölçeği” için .77-.80 arasında, "e-Öğrenme Sürecine İlişkin Memnuniyet Ölçeğì" için ise .91-.96 arasında olması ölçeklerin güvenirliği için bir kanıt olarak görülmektedir.

Anahtar Sözcükler: E-Öğrenme, e-hazır bulunuşluk, ememnuniyet, ölçek.

\footnotetext{
* Doç. Dr., Ankara Üniversitesi Enformatik Bölümü Ankara, Türkiye.
}

E-posta: gulbahar@ankara.edu.tr 


\section{GíRiş}

Her geçen gün eğitim kurumları e-Öğrenme yöntemini kullanarak uzmanlık kazandırdıkları yeni programlar açmaktadır. Bu programlar genellikle lisans öğretimi sonrası ve yetişkinler için tasarlanmaktadır. Güncel teknolojiler çok hızlı değişim gösterdiği için, sanal ortamlar olarak da ifade edilen elektronik ortamlarda eğitim alacak bireylerin hazır bulunuşluk düzeylerini bilmek eğitmen ve yöneticiler açısından önem taşımaktadır. e-Hazır Bulunuşluk olarak ifade edilen bu düzeye ilişkin verilere dayalı olarak öğretim süreçlerinde gerekli güncellemeler çok daha kolay ve doğru biçimde yapılabilir. Ayrıca yine elektronik ortamlarda eğitim alan kişilerin geçirdikleri eğitim yaşantısına dair memnuniyet düzeyleri de çok önemlidir. e-Memnuniyet olarak ifade edilen düzeyler incelenerek ve hangi faktörlerin memnuniyet düzeyini düşürdüğü belirlenerek, akademik ve idari açıdan gerekli düzenlemelerin yapılması ve sürecin çok daha etkili ve verimli bir hale getirilmesi söz konusu olabilir.

Türkiye'de eğitim kurumlarında teknolojik açıdan güncel ve yaygın bir alt yap1 olmaması, öğrenciler ve eğitmenler için teknik yeterlikler ve beceriler açısından belirlenmiş standartların bulunmaması, bu konuda yapılan çalışmaları güçleştirmektedir. Oysaki bu iki değişken e-Öğrenme sürecini doğrudan etkilemektedir. e-Öğrenme sürecinde girdi ve çıktı olarak nitelendirilebilecek bu iki değişkene ilişkin doğru sonuçlar elde edebilmek, geçerli ve güvenilir verilere dayalı olarak öğretim sürecinde gerekli değişim ve güncellemeleri yapabilmek öğretimin kalitesinin arttırılması açısından büyük önem taşımaktadır. Ayrıca uzaktan eğitim ve e-öğrenme yöntemi ile eğitim sunan kurumların, kaliteyi arttırmaya yönelik bir izleme ve değerlendirme sisteminin olmas1 gerekir. Kullanılan teknolojilerin, beklentilerin ve öğretim süreçlerinin hızla değiştiği günümüzde mevcut durumu belirleyerek sürekli iyileştirmeler için bilimsel yaklaşım kullanmak ve niteliğin iyileştirilmesi için önlemler alabilmek amacıyla belli zamanlarda öğrencilerin görüşlerine başvurmak, dönemlik ve yıllık olarak bu verileri karşılaştırmak, niteliği arttırmaya yönelik atılan adımların ve yapılan değişikliklerin sonucunu gözlemek gibi pek çok neden için, öğretim sisteminin girdi ve çıktısı olarak nitelendirilebilecek e-Hazır Bulunuşluk ve e-Memnuniyet bilgilerinin tutulması, analiz edilmesi ve yorumlanması çok önemlidir. Bu amaçla kullanılan ölçekler incelenmiş, ulusal ve uluslararası uygulamalar arasında akademik amaç ile kullanılabilecek ve kurumsal beklentilere tamamen yanıt verebilecek bir ölçeğe rastlanamamıştır. Benzer şekilde Türkçe dilinde geçerlik ve güvenirlik çalışmaları yapılmış ve bu iki konuyu ele alan ölçeklere de rastlanamamıştır. Doğrudan kullanılmaya 
uygun yabancı ya da Türkçe bir ölçek bulunamadığından, konuya ilişkin tüm ölçekler incelenerek daha kapsamlı ölçekler geliştirilmeye karar verilmiştir.

$\mathrm{Bu}$ bilgiler doğrultusunda bu çalışma bir ölçek geliştirme çalışmasıdır. $\mathrm{Bu}$ kapsamda, e-Hazır Bulunuşluk ve e-Memnuniyet düzeylerini belirleyen iki ayrı ölçek geliştirmek, bu ölçeklerin geçerlik ve güvenirlik çalışmalarını yaparak farklı çalışmalara katkı sağlayabilmek amaçlanmıştır.

\section{e-Öğrenme ve Hazır Bulunuşluk}

e-Öğrenme, öğrenci-merkezli yaklaşımlarla eğitim-öğretim süreçlerinin dönüşümü amacı ile bilişim teknolojilerinin kullanılması anlamına gelmektedir (Aoki, 2010). e-Hazır bulunuşluk ise bir kişi, kurum ya da ülkenin, e-Öğrenme sürecinde, yani bilgi ve iletişim teknolojilerinin kullanımı ve teknolojiden yararlanma açısından ne kadar hazır, istekli ve donanımlı olduğu konusunda geldiği düzeyin ölçülmesi ile elde edilen bilgidir (Dada, 2006). e-Öğrenme çıtılarını etkileyen faktörler konusunda oldukça fazla çalışma olmasına rağmen, hazır bulunuşluk ve hazır bulunuşluk faktörlerinin e-Öğrenme çıktıları üzerine etkisini irdeleyen araştırma sayısı oldukça azdır (Keramati, Afshari-Mofrad \& Kamrani, 2011). Ayrıca özellikle yüksek öğretim düzeyinde e-Hazır bulunuşluk konusunda alan yazında sınırlı sayıda çalışma yer almaktadır (Darab \& Montazer, 2011).

Economic Intelligence Unit (2009) tarafından yapılan araştırmaya göre 69 ülke içerisinde Türkiye, e-Hazır Bulunuşluk açısından 43. sırada yer almaktadır. Bu sıralamada, bağlanabilirlik ve teknik altyapı (\%20), iş çevresi (\%15), sosyal ve kültürel çevre (\%15), toplumsal (legal) çevre (\%10), devlet politikaları ve öz görevleri (\%15) ile tüketici ve iş adaptasyonu (\%25) boyutları belirtilen yüzde ağırlıklarında ele alınmıştır. Genç nüfusun yoğunluğuna rağmen raporda belirtilen veriler oldukça düşüktür. $\mathrm{Bu}$ gösterge ülkemizde bilişim teknolojilerinin devlet ve ticaret gibi hızlı bilgi dönüşümü yaşanan süreçlerde bireyler tarafından çok fazla kullanılmadığını göstermektedir.

Alanyazın incelendiğinde, e-Hazır bulunuşluk konusunda yapılan çalışmalarda bilişim teknolojileri kullanım düzeyi yani teknik yeterlikler ile teknoloji ve kaynaklara erişim faktörlerinin mutlaka ele alındığ görülmektedir (Stephen, Mutula \& Brakel, 2006; Hanafizadeh, Hanafizadeh \& Khodabakhshi, 2009). Bu nedenle bilişim teknolojileri gibi çevresel faktörlerin yanı sıra kişisel özellikler de e-Hazır bulunuşluk düzeyinin belirlenmesi açısından önemlidir (Dada, 2006). Shraim ve Khlaif (2010) öğrencilerin e-Öğrenme sürecine ne derece hazır bulunduklarını ortaya çıkarmaya yönelik bir çalışma yapmışlar ve kullanışl1lık, kişisel yeterlik, motivasyon ve güçlükler olmak üzere 4 boyut ele almışlardır. 
Watkins, Leigh ve Triner (2004), e-Hazır bulunuşluk düzeyini inceledikleri makalelerinde teknolojiye erişim, teknik beceriler, motivasyon, çevrimiçi ses ve görüntü, İnternet tartışmaları ve başarıyı etkileyen faktörleri ele almışlardır. Özetlemek gerekirse, e-Hazır bulunuşluğa ilişkin farklı araştırmalarda kişisel özellikler, teknik yeterlikler, teknolojiye erişim, motivasyon ve başarıyı etkileyen faktörlere ilişkin boyutların ele alındığ 1 görülmektedir.

\section{e-Öğrenme ve Memnuniyet}

e-Memnuniyet düzeyi, öğrencinin bütün bir sürece ilişkin düşüncelerini ortaya çıkarması bakımından çok önemlidir. Ayrıca, yıllık olarak bu düzeyin sürekli kontrol edilmesi ve bir önceki yıl ile karşılaştırılması, yapılan düzenlemelerin ne derece başarılı olduğuna dair bilgi verecektir. eMemnuniyet düzeyini etkileyen faktörlere bakıldığında çalışmaların belli konularda ortak noktaları olduğu görülmektedir. Örneğin, Beqiri, Chase ve Bishka (2009) öğrenci memnuniyetini etkileyen faktörleri ortaya çıkarmaya yönelik bir araştırma yapmışlar, e-Öğrenme teknolojileri ile öğrenmeye karşı olumlu tutumu olan ve bu teknolojileri kullanma konusunda biraz donanımı olan kişilerin memnuniyetlerinin daha fazla olduğu sonucuna ulaşmışlardır. Pena ve Yeung (2010) öğrencilerin bilgisayar kullanımı konusundaki yeterliliklerinin memnuniyetlerini etkileyip etkilemediklerini araştırmışlar, yeterlik düzeyi düştükçe memnuniyet düzeyinin de düştüğü sonucuna ulaşmışlardır.

Jung-Wan ve Mendlinger (2011) kişisel yeterlik algısının e-Öğrenme yöntemini kabul etme ve memnuniyet üzerine etkilerini incelemişler ve iki önemli bulguya ulaşmışlardır: (1) Kişisel yeterlik algısı e-Öğrenme sistemlerine karşı olan tutumu etkilemektedir ve (2) e-Öğrenme sistemlerinin kullanışlılığı memnuniyeti olumlu yönde etkilemektedir. Palmer ve Holt (2009) tarafından yapılan çalışmaya göre öğrencilerin dijital ortamda öğrenme ve teknoloji kullanımı konusunda kendilerine duydukları güven, başarılı olmak için kendilerinden neler beklendiğini anlamış olmaları ve öğrenme sürecinde ne derece nitelikli eğitim aldıkları konuları, öğrencilerin memnuniyet düzeylerini yaklaşık \%70 oranında açıklayabilmektedir. Benzer şekilde, Bray, Aoki ve Dlugosh (2008) öğrenci memnuniyeti konusunda yaptıkları araştırmanın sonucunda (1) e-Öğrenme sürecinin güçlükleri ile baş edebilen, (2) bilgisayar kullanmayı kolay bulan, (3) eğitmenler ile rahat iletişim kurabilen ve (4) öğrenme sürecinde sosyal etkileşimi tercih etmeyen yani bireysel öğrenme sürecini tercih eden öğrencilerin memnuniyet düzeylerinin daha yüksek olduğu bulgusuna ulaşmışlardır. 
Bir başka araştırmaya göre, kurumsal açıdan sunulan olanaklar ile akademik ve idari personel yeterlik düzeyleri yükseldikçe öğrenci memnuniyeti de yükselmektedir, ayrıca öğrencilerin teknoloji konusundaki yeterlikleri de memnuniyet düzeylerini etkilemektedir (Machado, 2007). Hye-Jung ve Rha (2009) yaptıkları araştırmada web-tabanlı öğretim süreçlerinde yapılandırılmış öğretim ve etkileşimli öğretim yaklaşımlarını karşılaştırdıkları bir çalışma yapmışlar, her iki yaklaşımında çok önemli olduğunu ve birbirleri yerine kullanılabileceklerini belirtmişlerdir. Araştırmacılar ayrıca, yapılandırılmış derse katılan öğrencilerin memnuniyetlerinin daha yüksek olduğunu, etkileşimi yüksek olan derse katılanların ise başarılarının daha yüksek olduğunu belirtmişlerdir. Palmer ve Holt (2010) öğrenci memnuniyetine ilişkin yaptıkları araştırmanın sonucunda öğrencilerin büyük bir kısmının Öğretim Yönetim Sistemi tarafindan sunulan özelliklere değer verdiği, bu özelliklere bağlı olarak memnuniyetlerinin yükseldiğini belirtmişlerdir.

Ilgaz (2008), "uzaktan eğitimde teknoloji kabulünün ve topluluk hissinin öğrenen memnuniyetine katkısı" konulu çalışması için bir memnuniyet ölçeği geliştirmiştir. Toplam 34 soru ve 6 faktörden oluşan ölçeğin boyutları şu şekilde belirlenmiştir: öğrenci-öğrenci etkileşimi, öğrenci-öğretmen etkileşimi, çevrimiçi dersler, teknik destek, basılı materyaller ve yüz yüze etkinlikler.

Alan yazından çıkan bu sonuçlara dayalı olarak e-Memnuniyet düzeyini belirlemek amacıyla, bilgisayar kullanımı konusundaki kişisel yeterlik, öğretim süreci, öğretim içeriği, e-eğitmen yeterliği, e-Öğrenme teknolojileri ile öğrenmeye karşı olumlu tutum, e-Öğrenme sistemlerinin kullanışlıllğı ve etkileşim düzeyi boyutlarına ilişkin çalışmalar yapıldığı belirlenmiştir.

\section{YÖNTEM}

\section{Örneklem}

Araştırmanın evreni, bir devlet üniversitesinin tamamen e-Öğrenme yöntemi ile eğitim-öğretim yapan farklı programlarına kayıtlı 3270 öğrenciden oluşmaktadır. Çalışmadaki her iki ölçekte öğrenme yönetim sistemini aktif olarak kullanan öğrenciler tarafından iki haftalık zaman dilimlerinde yanıtlanmıştır. E-hazır bulunuşluk ölçeği 2963 öğrenci, eMemnuniyet ise 2706 öğrenci tarafından yanıtlanmıştır. Demografik bilgilere yanıt veren 2509 öğrenciden 1110 kişi (\%44,2) erkek ve 1399 kişi $(\% 55,8)$ kadındır. Bu katılımcılardan 1238 (\%49,3) kişi bekâr iken 1271 kişi $(\% 50,7)$ evlidir. Katılımcıların tamamı yetişkindir. 


\section{Ölçme Araçları}

\section{e-Öğrenme Sürecine İlişkin Hazır Bulunuşluk ve Beklenti Ölçeği (e-Hazır Bulunuşluk Ölçeği)}

Öğrencilerin e-Öğrenme yöntemi ile öğrenme sürecine ne düzeyde hazır olduklarını belirleyebilmek için araştırmacı tarafından bir ölçek geliştirilmiştir. Ölçekte yer alan maddeler ve boyutlar, alan yazın incelemesi sonuçları, farklı yüksek öğretim kurumlarının uyguladıkları ölçekler ve Watkins, Leigh ve Triner (2004), GeoSINC International (2002) ve KING ICT (2011) gibi araştırmacıların ve kurumların yayınlarına dayalı olarak belirlenmiştir. Ölçek için 5 ayrı uzmandan görüş alınmış ve güncellemeler yapılmıştır. Bu makale kapsamında verilen analiz sonuçları ölçeğin ilk pilot uygulama sonucudur.

Ölçek "Kişisel Özellikler" boyutunda 5, "Teknolojiye Erişim" boyutunda 4, "Teknik Beceriler" boyutunda 6, "Motivasyon ve Tutum" boyutunda 6 ve son olarak "Başarıyı Etkileyen Faktörler" boyutunda 6 soru olmak üzere toplam 5 boyut ve 27 sorudan oluşmaktadır. Ölçekte 5-Hemen hemen her zaman, 4-S1k s1k, 3-Zaman zaman, 2-Nadiren ve 1-Hemen hemen hiçbir zaman olmak üzere 5'li likert tipi derecelendirme uygulanmıştır.

\section{Ölçeği) \\ e-Öğrenme Sürecine İlişkin Memnuniyet Ölçeği (e-Memnuniyet}

$\mathrm{Bu}$ ölçek geliştirme çalışması kapsamında geliştirilen ikinci ölçek, öğrencilerin e-Öğrenme yöntemi ile öğrenme sürecinden ne düzeyde memnun kaldıklarını belirlemek amacıyla yine araştırmacı tarafından geliştirilmiştir. Bu ölçek, yüksek öğretim ve e-Öğrenme konusunda kalite çalışmalarını sürdüren çok sayıda kurumun kendi ölçümleri için kullandıkları çok sayıda dereceleme ölçeği ve oluşturdukları standarlar incelenerek ve Barker (2002), Swedish National Agency for Higher Education (2008), Naidu (2006) ve Wright (2003) gibi konuya ilişkin çalışmalar göz önünde bulundurularak geliştirilmiştir. Ölçek için öncelikle 3 uzman görüşü alınmış, daha sonra pilot uygulama yapılmıştır. Pilot uygulama sonucunda istatistiksel analiz sonuçlarına dayalı olarak iki ayrı uzmanın görüşü ile bazı maddeler çıkarılmıştır. Bu makalede verilen analiz sonuçları, güncellenmiş ölçeğin tekrar uygulanması sonucu elde edilen bulgulardır. Ölçekte "İletim \& Kullanışlilık" boyutunda 5, "Öğretim Tasarımı" boyutunda 6, "Öğretim Elemanları" boyutunda 5, "Ders İzlencesi" boyutunda 6, "Ders İçeriği \& Öğretim Materyalleri" boyutunda 6, "Etkileşim ve İşbirliğì" boyutunda 5 ve "Değerlendirme" boyutunda 5 olmak üzere 
toplam 38 soru vardır. Diğer ölçekte olduğu gibi bu ölçek içinde 5-Hemen hemen her zaman, 4-S1k s1k, 3-Zaman zaman, 2-Nadiren ve 1-Hemen hemen hiçbir zaman olmak üzere 5'li likert tipi derecelendirme uygulanmıştır.

Her iki ölçek için öngörülen faktör yapıları hem açımlayıcı faktör analizi (AFA) hem de doğrulayıc faktör analizi (DFA) ile incelenmiştir. Değişkenler arasındaki ilişkilere dayalı olarak faktör yapısını keşfetmek amacıyla öncelikle açımlayıcı faktör analizi yapılmıştır. Daha sonra, modelveri uyumunu incelemek amacıyla doğrulayıcı faktör analizi kullanılmıştır (Tabachnick \& Fidell, 2001). Ayrıca doğrulayıcı faktör analizi kapsamında modelin geçerliğini test etmek amacıyla uyum indeksleri de incelenmiştir. Yaygın biçimde ele alınan uyum indeksleri Ki-Kare Uyum Testi, İyilik Uyum İndeksi (GFI), Düzeltilmiş İyilik Uyum İndeksi (AGFI), Ortalama Hataların Karekökü (RMR ya da RMS) ve yaklaşık hataların karekökü (RMSEA) olarak belirlenmiştir. Alanyazı incelendiğinde, doğrulayıcı faktör analizi ile hesaplanan $\chi 2 /$ sd oranının 5 değerinden küçük olması, modelin gerçek verilerle uyumunun göstergesi olarak yorumlanmaktadır (Sümer, 2000). Model veri uyumunun sağlanabilmesi için ise GFI ve AGFI değerlerinin 0.09 değerinden büyük olmas1, RMSEA değerinin 0.08 değerinden küçük, RMR değerinin ise 0.05 değerinden küçük olmas1 beklenir. Analiz sonuçlarına göre kabul edilebilir değerler Tablo 1'de görülmektedir.

Tablo 1. Çalışma kapsamında ele alınan uyum indeksleri ve değerleri

\begin{aligned} & \hline Uyum İndeksleri Kriterler \\ & \hline$\chi^{2} / \mathrm{sd}<5 / 1 \\ &$\hline GFI $>0.90 \\ &$\hline AGFI $>0.90 \\ &$\hline RMSEA $<0.08 \\ &$\hline S-RMR $<0.05 \\ &$\hline CFI $>0.90 \\ &$\hline NNFI $>0.90 \\ &$\hline IFI $>0.90 \\ &$\hline\end{aligned}

Ayrıca, faktör yapıları belirlendikten sonra ölçekler ve alt boyutları için Cronbach alfa iç tutarlılık katsayıları da hesaplanmıştır. 


\section{BULGULAR}

\section{e-Öğrenme Sürecine İlişkin Hazır Bulunuşluk ve Beklenti Ölçeği için Geçerlik ve Güvenirlik Analizlerine İlişsin Bulgular}

\section{Açımlayıcı Faktör Analizi Sonuçları}

Tablo 2. "e-Hazır Bulunuşluk Ölçeği" için açımlayıcı faktör analizi sonuçları

\begin{tabular}{|c|c|c|c|c|c|}
\hline $\begin{array}{l}\text { Madde } \\
\text { No }\end{array}$ & $\begin{array}{c}\text { Teknik } \\
\text { Beceriler }\end{array}$ & $\begin{array}{c}\text { Başarıyı } \\
\text { Etkileyen } \\
\text { Faktörler }\end{array}$ & $\begin{array}{c}\text { Teknolojiye } \\
\text { Erişim }\end{array}$ & $\begin{array}{c}\text { Motivasyon } \\
\text { ve Tutum }\end{array}$ & $\begin{array}{c}\text { Kişisel } \\
\text { Özellikler }\end{array}$ \\
\hline s12 &, 815 & & & & \\
\hline s13 & ,813 & & & & \\
\hline $\mathrm{s} 10$ & ,813 & & & & \\
\hline s11 & ,801 & & & & \\
\hline s15 & ,776 & & & & \\
\hline s19 & ,739 & & & & \\
\hline s14 &, 690 & & & & \\
\hline s5 & ,580 & & & & \\
\hline s24 & & ,846 & & & \\
\hline s22 & & ,799 & & & \\
\hline s23 & & ,785 & & & \\
\hline s25 & & ,780 & & & \\
\hline s26 & &, 753 & & & \\
\hline s27 & &, 572 & & & \\
\hline s6 & & &, 763 & & \\
\hline s7 & & &, 743 & & \\
\hline s8 & & & 642 & & \\
\hline $\mathrm{s} 2$ & & & 605 & & \\
\hline s18 & & & & ,795 & \\
\hline s16 & & & & ,784 & \\
\hline s17 & & & &, 753 & \\
\hline $\mathrm{s} 21$ & & & &, 436 & \\
\hline s1 & & & & & ,687 \\
\hline s3 & & & & & ,658 \\
\hline s9 & & & & &, 549 \\
\hline s4 & & & & & ,401 \\
\hline
\end{tabular}

Ölçek 2963 ön lisans öğrencisi tarafindan yanıtlanmış, ancak uygun olmayan veriler çıkarıldıktan sonra analize 2699 kişiden alınan verilerle devam edilmiştir. Analiz için Kaiser-Meyer-Olkin (KMO) değeri 0,941 ve Barlett's testi anlamlı $(\mathrm{p}<0.01)$ bulunmuştur. Ölçekte toplam 27 madde yer almaktadır ve analiz sonucu ölçeğin öngörüldüğü gibi 5 faktörden oluştuğunu göstermiştir. Faktör döndürme sonrasında birden fazla faktör altında yer alabildiği görülen bir madde (20 nolu madde) ölçekten 
çıkarılmıştır. Ayrıca bazı sorular farklı faktörler altında belirmiştir. Uzman incelemesi sonucunda faktör başlığ değişen soruların yeni hali ile hiç bir sorun yaratmadığı hatta daha uygun bir başlığa yerleştiği sonucuna ulaşılmıştır. Faktör başlıklarında da hiç bir değişime gerek duyulmamıştır. Açımlayıcı faktör analizi sonuçları Tablo 2'de görülmektedir.

\section{Doğrulayıcı Faktör Analizi Sonuçları}

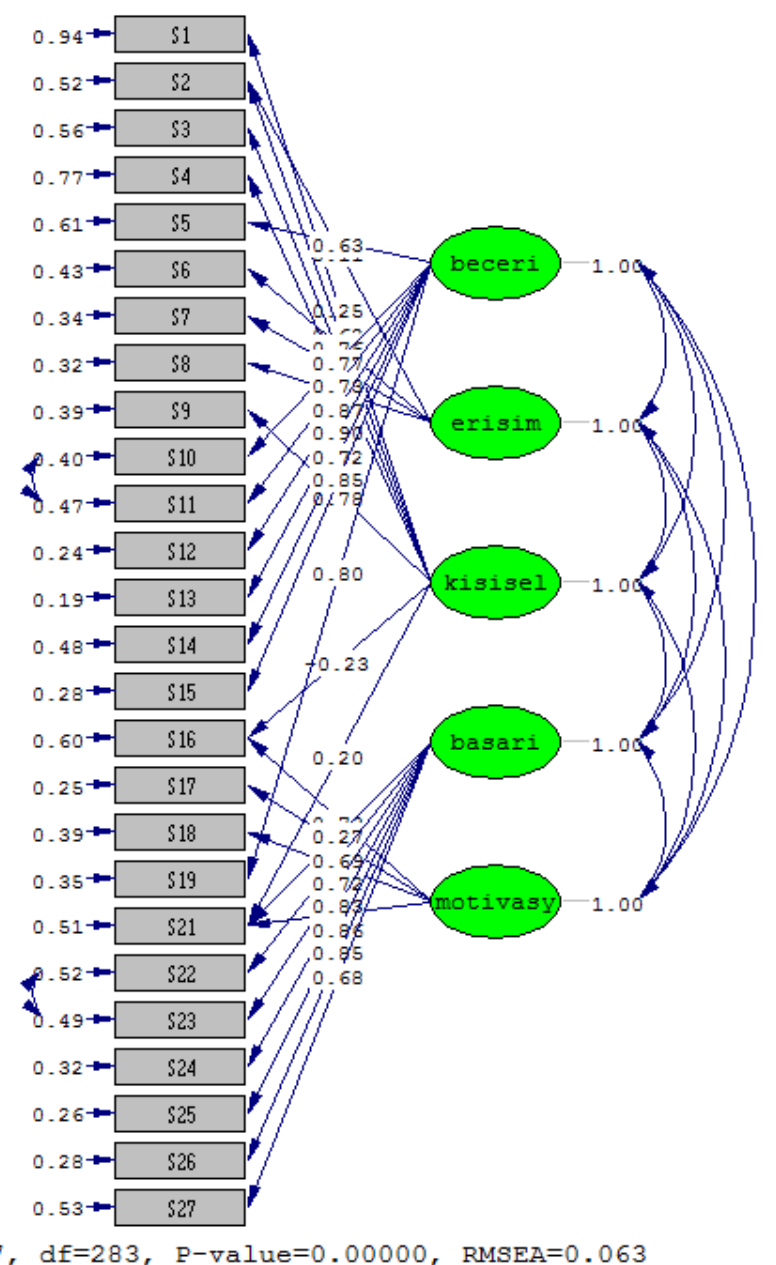

Şekil 1. "e-Hazır Bulunuşluk Ölçeği” için Doğrulayıcı Faktör Analizi Sonuçları

“e-Hazır Bulunuşluk Ölçeğii”nin 5 faktörden oluşan modelinin toplanan verilerle ne derece uyum gösterdiğini incelemek amaciyla yapılan 
doğrulayıcı faktör analizinde model-veri uyumu için hesaplanan ki-kare değerli anlamlı bulunmuştur, $\chi 2(289, \mathrm{~N}=2699)=5695.31, \mathrm{p}<.000$. Lisrel 8.7 programı kullanılarak yapılan bu ilk analiz ile hesaplanan farklı uyum istatistikleri ise şu şekildedir: RMSEA $=0.083, \mathrm{~S}-\mathrm{RMR}=0.064, \mathrm{GFI}=0.86$, AGFI $=0.83, \mathrm{CFI}=0.96, \mathrm{NNFI}=0.96, \mathrm{IFI}=0.96$. Bu sonuçlarda bazı değerler uygun aralıklar içinde bulunmamasından dolayı programın önerdiği modifikasyonlar gerçekleştirilmiştir. $\mathrm{Bu}$ kapsamda, 10-11 ve 22-23 maddeleri arasındaki hatalara ilişkin korelasyonlar serbest bırakılmıştır. Ayrica 2, 16 ve 21 numaralı maddelerin birden fazla faktörle ilişkili olduğu belirlenmiş ve bu bağlantılar analize dahil edilmiştir. Bu modifikasyonlardan sonra elde edilen veriler $[\chi 2(283, \mathrm{~N}=2699)=3358.17, \mathrm{p}<.000$, RMSEA $=$ $0.063, \mathrm{~S}-\mathrm{RMR}=0.048, \mathrm{GFI}=0.91, \mathrm{AGFI}=0.89, \mathrm{CFI}=0.98, \mathrm{NNFI}=0.98$, $\mathrm{IFI}=0.98]$ modelin iyi bir uyum gösterdiği sonucunu ortaya koymuştur. Doğrulayıcı faktör analizi sonuçları Şekil 1'de görülmektedir.

\section{Güvenirlik Analizi Sonuçları}

e-Öğrenme Sürecine İlişsin Hazır Bulunuşluk ve Beklenti Ölçeği içim faktör bazında güvenirlik katsayıları ise Tablo 3'de verilmiştir. Ölçeğin tamamına ait Cronbach alfa güvenirlik katsayısı ise 0,93 olarak bulunmuştur. Ölçeğin 26 maddeden oluşan son hali Ek-1'de verilmiştir.

Tablo 3. "e-Hazır Bulunuşluk Ölçeğgi “için güvenirlik analizi sonuçları

\begin{tabular}{lcc}
\hline Faktörler & $\begin{array}{c}\text { Madde } \\
\text { Sayısı }\end{array}$ & $\begin{array}{c}\text { Güvenirlik } \\
\text { Katsayısı (a) }\end{array}$ \\
\hline Kişisel Özellikler & 4 & 0,80 \\
\hline Teknolojiye Erişim & 4 & 0,77 \\
\hline Teknik Beceriler & 8 & 0,79 \\
\hline Motivasyon ve Tutum & 4 & 0,79 \\
\hline Başarıyı Etkileyen Faktörler & 6 & 0,77 \\
\hline
\end{tabular}

\section{e-Memnuniyet Ölçeği için Geçerlik ve Güvenirlik Analizlerine İlişkin Bulgular}

\section{Açımlayıcı Faktör Analizi Sonuçları}

Ölçek 2706 ön lisans öğrencisi tarafindan yanıtlanmış, ancak uygun olmayan veriler çıkarıldıktan sonra analize 1991 kişiden alınan verilerle devam edilmiştir. Analiz için Kaiser-Meyer-Olkin (KMO) değeri 0,982 ve Barlett's testi anlamlı $(\mathrm{p}<0.01)$ bulunmuştur. Ölçekte toplam 38 madde yer almaktadır ve yapılan ilk analiz sonucunda ölçeğin öngörüldüğü gibi 7 faktörden değil, 4 faktörden oluştuğu sonucuna ulaşılmıştır. 
Tablo 4. "e-Memnuniyet Ölçeğì" için açımlayıcı faktör analizi sonuçları

\begin{tabular}{|c|c|c|c|c|}
\hline Madde No & $\begin{array}{c}\text { Etkileșim ve } \\
\text { Değerlendirme }\end{array}$ & $\begin{array}{c}\text { İletim ve } \\
\text { Kullanışlılık }\end{array}$ & $\begin{array}{l}\text { Öğretim } \\
\text { Süreci }\end{array}$ & Öğretim İçeriği \\
\hline s31 &, 804 & & & \\
\hline $\mathrm{s} 32$ & ,790 & & & \\
\hline $\mathrm{s} 30$ & ,773 & & & \\
\hline s33 &, 760 & & & \\
\hline s36 & ,755 & & & \\
\hline $\mathrm{s} 35$ & ,728 & & & \\
\hline s34 & , 720 & & & \\
\hline s38 & ,707 & & & \\
\hline s37 & ,701 & & & \\
\hline s29 & ,623 & & & \\
\hline s3 & & ,819 & & \\
\hline s4 & & ,812 & & \\
\hline s2 & &, 714 & & \\
\hline s5 & & ,703 & & \\
\hline s1 & & ,692 & & \\
\hline s6 & &, 540 & & \\
\hline s7 & & ,538 & & \\
\hline $\mathrm{s} 13$ & & & ,725 & \\
\hline s14 & & & ,707 & \\
\hline $\mathrm{s} 12$ & & & 676 & \\
\hline $\mathrm{s} 15$ & & & ,646 & \\
\hline $\mathrm{s} 16$ & & & ,590 & \\
\hline $\mathrm{s} 10$ & & & ,556 & \\
\hline s9 & & & ,535 & \\
\hline s11 & & & ,534 & \\
\hline s24 & & & & ,744 \\
\hline $\mathrm{s} 25$ & & & &, 736 \\
\hline $\mathrm{s} 23$ & & & & ,697 \\
\hline s26 & & & & ,669 \\
\hline
\end{tabular}

Faktör döndürme sonrasında birden fazla faktör altında yer alabildiği görülen 9 madde $(8,17,18,19,20,21,22,23$ ve 24 numaralı maddeler) sira ile ölçekten çıkarılmıştır. Oluşan yeni faktörler için iki uzman tarafından yeniden faktör başlı̆g belirlenmiştir. Maddeler incelenerek bu başlıklar önceden belirlenen başlıklar arasına "ve" bağlacı eklenerek oluşturulmuştur. Önceden öngörülen bir faktörün ise (Ders İzlencesi) tamamen yok olduğu gözlenmiştir. Ölçeğe ilişkin açımlayıcı faktör analizi sonuçlarına göre maddeler ve faktörleri Tablo 4'te görülmektedir. 


\section{Doğrulayıcı Faktör Analizi Sonuçları}

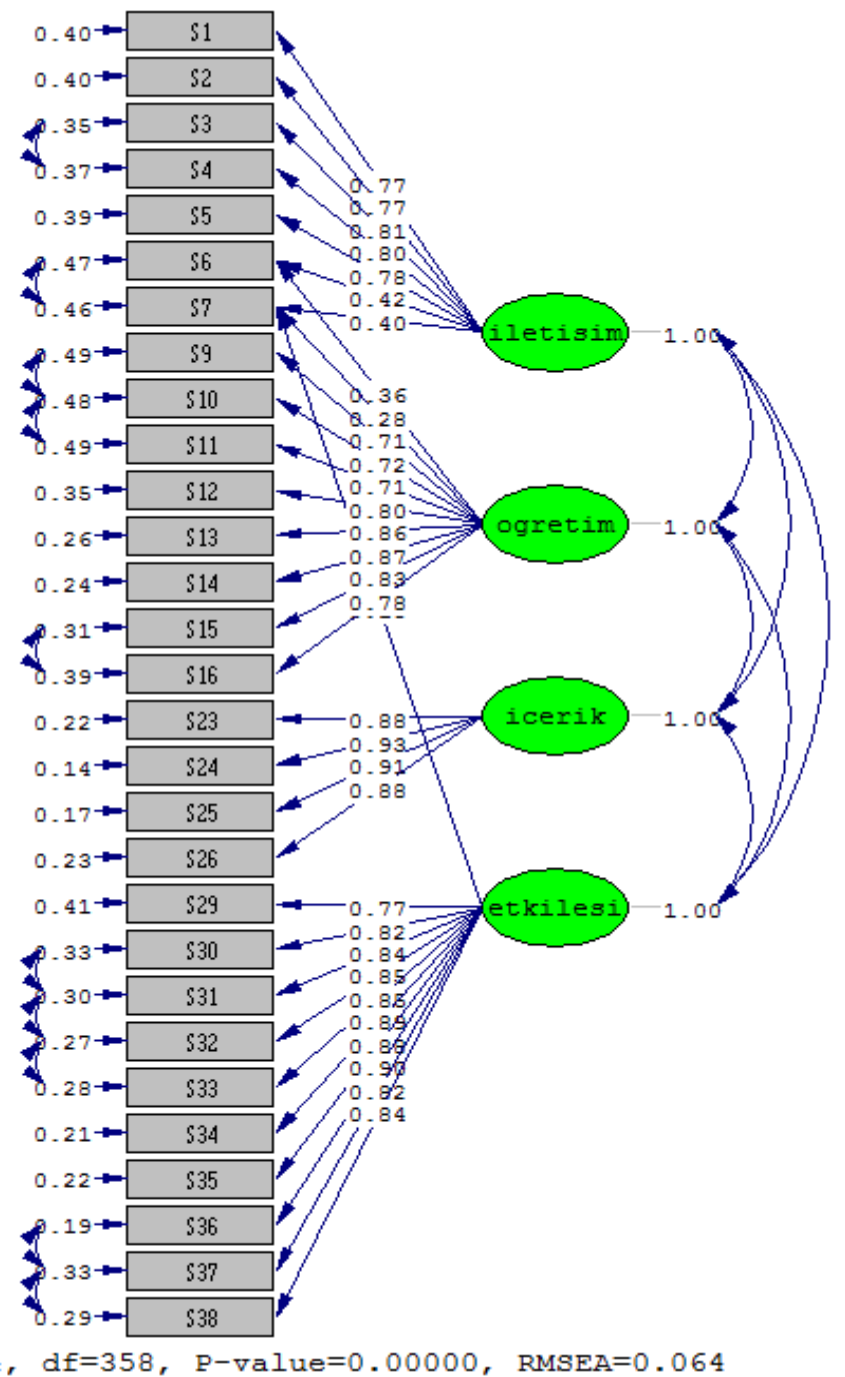

Şekil 2. "e-Memnuniyet Ölçeğì için doğrulayıcı faktör analizi sonuçları

“e-Memnuniyet Ölçeği”nin 4 faktörden oluşan modelinin toplanan verilerle ne derece uyum gösterdiğini incelemek amaciyla Lisrel 8.7 programı kullanılarak yapılan ilk analiz sonunda elde edilen değerlerin $[\chi 2$ $(371, \mathrm{~N}=1991)=7885.92, \mathrm{p}<.000, \mathrm{RMSEA}=0.101, \mathrm{~S}-\mathrm{RMR}=0.049, \mathrm{GFI}=$ $0.79, \mathrm{AGFI}=0.75, \mathrm{CFI}=0.98, \mathrm{NNFI}=0.98, \mathrm{IFI}=0.98]$ uygun aralıklar içinde 
bulunmamasından dolayı programın önerdiği modifikasyonlar gerçekleştirilmiştir. 3-4, 6-7, 9-10, 10-11, 15-16, 30-31, 31-32, 32-33, 36-37, 37-38 maddeleri arasındaki hatalara ilişkin korelasyonlar serbest bırakılmıştır. Ayrıca 6 ve 7 numaralı maddelerin birden fazla faktörle ilişkili olduğu belirlenmiş ve bu bağlantılar analize dahil edilmiştir. $\mathrm{Bu}$ modifikasyonlardan sonra elde edilen veriler $[\chi 2(358, \mathrm{~N}=2699)=3278.64$, $\mathrm{p}<.000, \mathrm{RMSEA}=0.064, \mathrm{~S}-\mathrm{RMR}=0.037, \mathrm{GFI}=0.90, \mathrm{AGFI}=0.88, \mathrm{CFI}=$ $0.99, \mathrm{NNFI}=0.99, \mathrm{IFI}=0.99]$ modelin iyi bir uyum gösterdiği sonucunu ortaya koymuştur. Doğrulayıcı faktör analizi sonuçları Şekil 2'de görülmektedir. Maddelerin faktörleri ile olan ilişkilerini gösteren standardize edilmiş katsayılar .26 ile .89 arasında değişmektedir ve .01 düzeyinde anlamlidir.

\section{Güvenirlik Analizi Sonuçları}

e-Öğrenme Sürecine İlişkin Hazır Bulunuşluk ve Beklenti Ölçeği içim faktör bazında güvenirlik katsayıları ise Tablo 5'de verilmiştir. Ölçeğin tamamına ait Cronbach alfa güvenirlik katsayısı ise 0,97 olarak bulunmuştur. Yeni belirlenen dört faktör için ise iki uzman tarafından yeniden faktör başlıkları yine Tablo-5'de belirtilmiştir. Ölçeğin 29 maddeden oluşan son hali Ek-2'de yer almaktadır.

Tablo 5. "e-Memnuniyet Ölçeğì" için güvenirlik analizi sonuçları

\begin{tabular}{lcc}
\hline Faktörler & $\begin{array}{c}\text { Madde } \\
\text { Sayısı }\end{array}$ & $\begin{array}{c}\text { Güvenirlik } \\
\text { Katsayısı (o) }\end{array}$ \\
\hline İletim ve Kullanışlılık & 7 & 0,91 \\
\hline Öğretim Süreci & 8 & 0,93 \\
\hline Öğretim İçeriği & 4 & 0,94 \\
\hline Etkileşim ve Değerlendirme & 10 & 0,96 \\
\hline
\end{tabular}

\section{TARTIŞMA VE SONUÇ}

Hızla gelişen ve değişen teknolojiler, eğitim alanında da yaygın biçimde kullanılmaktadır. Teknolojilerin etkisi ve verimliliğine ilişkin pek çok araştırma yürütülmektedir. $\mathrm{Bu}$ araştırmalar Zawacki-Richter (2009) tarafindan da belirtildiği üzere (1) Uzaktan eğitim sistemleri ve kuramlar, (2) Yönetim, organizasyon ve teknoloji ile (3) uzaktan eğitimle öğretme ve öğrenme olmak üzere 3 grupta ele alınabilir. Mikro düzey olarak da ifade edilen öğretme ve öğrenme başlığı özellikle ögrenen topluluklarda etkileşim ve iletişim, öğretim tasarımı ve öğrenci özellikleri gibi boyutlarda sürece ve bileşenlerine odaklanmaktadır. Uzaktan eğitim, tamamen öğrenci-merkezli 
bir öğretim yaklaşımıdır ve bu nedenle öğrencilere ve yaşadıkları sürece ilişkin araştırma sonuçları, tüm paydaşlara öğretimin kalitesini arttırmak açısından farklı yararlar sağlayacaktır.

$\mathrm{Bu}$ düşünceden hareket ile bu çalışmada, e-Öğrenme sürecini doğrudan etkileyen iki değişken (1) öğrencilerin giriş davranışları yani e-Öğrenme Sürecine İlişkin Hazır bulunuşluk düzeyleri ve beklentileri ile (2) e-Öğrenme sürecindeki farklı boyutlara ilişkin memnuniyet düzeyleri konusunda ölçümler yapmak amacıyla iki ölçek geliştirilmiştir. Genel olarak her iki ölçek için ayrı ayrı yapılan analizler ile ortaya konulan faktör yapılarına ilişkin her bir ölçme modeli için model-veri uyumları doğrulayıcı faktör analizi incelenmiştir. Analiz sonuçlarının model-veri uyumu için belirtilen ölçütleri karşıladığı ifade edilebilir. Ölçek puanları için hesaplanan güvenirlik katsayılarının da genel olarak "e-Öğrenme Sürecine İlişkin Hazır Bulunuşluk ve Beklenti Ölçeği” için .77-.80 arasında, "e-Öğrenme Sürecine İlişkin Memnuniyet Ölçeği” için ise .91-.96 arasında olması ölçeklerin güvenirliği için bir kanıt olarak görülmektedir.

"e-Öğrenme Sürecine İlişkin Hazır Bulunuşluk ve Beklenti Ölçeğì" açısından araştırmacı tarafından ilk aşamada öngörülen faktör yapılarında hiç bir değişiklik olmamıştır. Bu sonuç, "Teknik Beceriler", "Başarıyı Etkileyen Faktörler", "Teknolojiye Erişim", "Motivasyon ve Tutum" ve "Kişisel Özellikler" olmak üzere 5 faktör olarak belirlenen başlıkların hazır bulunuşluk ve beklenti boyutlarını yordama açısından anlamlı olduğu şeklinde yorumlanabilir. Gelecekteki çalışmalar belirlenen bu boyutları tekrar ele almak ile birlikte olası yeni bir boyutun eklenebilme olasılığ 1 konusuna yoğunlaşabilir.

Diğer yandan, "e-Öğrenme Sürecine İlişkin Memnuniyet Ölçeği" için ise "İletim \& Kullanışlılık", "Öğretim Tasarımı", "Öğretim Elemanları", "Ders İzlencesi", "Ders İçeriği \& Öğretim Materyalleri", "Etkileşim ve İşbirliği" ve "Değerlendirme" olmak üzere 7 boyut şeklinde öngörülen yap1, "İletim ve Kullanışl1l1k”, “Öğretim Süreci”, “Öğretim İçeriği” ve "Etkileşim ve Değerlendirme" olmak üzere 4 faktörlü bir yapı olarak farklılaşmıştır. Bu farklılaşmada; "İletim \& Kullanışlılık" boyutu korunurken, "Öğretim Tasarımı" ve "Öğretim Elemanları" boyutları "Öğretim Süreci" olarak daha genel bir ifade ile bütünleşmiş, "Ders İzlencesi" boyutunda tüm maddelerin atılması gerektiğinden bu faktör tamamen göz ardı edilmiş, "Ders İçeriği \& Öğretim Materyalleri” boyutu "Öğretim İçeriği" olarak yeniden adlandırılmış, "Etkileşim ve İşbirliği" ve "Değerlendirme" boyutları ise "Etkileşim ve Değerlendirme" olarak yeniden adlandırılmıştır. Bu yeniden adlandırılma sürecinde en önemli neden ilgili başlık altındaki 1-2 maddenin yer değiştirmesinden kaynaklanmaktadır. Burada en ilginç sonuç "Ders İzlencesi" faktörüne ait tüm maddelerde analiz sonuçlarına göre sorun 
yaşanmasıdır. Bu faktör alanyazında çok önemli bir faktör olmasına rağmen, ölçek geliştirme çalışmasının uygulandığı grupta eğitmenlerin genellikle detaylı bir e-ders izlencesi kullanmadığı gözlenmiştir. Bu mevcut durum, ölçekte bu faktörün yok olmasına neden olmuş olabilir. Ölçeklere ilişkin faktörler Şekil 3’te görülmektedir.

1. Teknik Beceriler

2. Başarıyı Etkileyen Faktörler

3. Teknolojiye Erişim

4. Motivasyon ve Tutum

5. Kişisel Özellikler

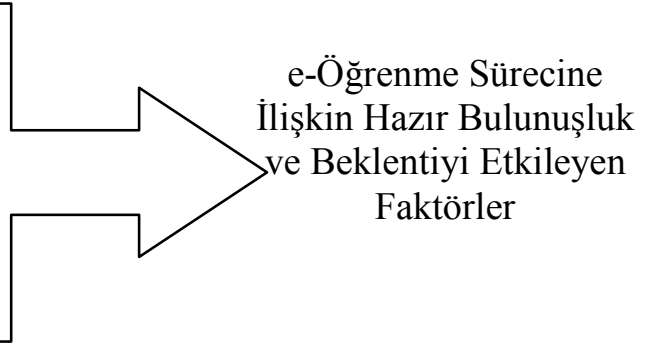

1. İletim ve Kullanışl1lık

2. Öğretim Süreci

3. Öğretim İçeriği

4. Etkileşim ve Değerlendirme

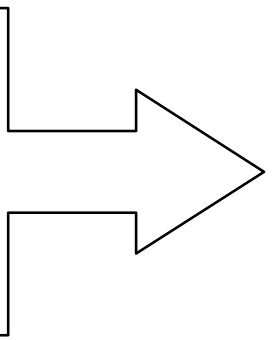

e-Öğrenme

Sürecine İlişkin

Memnuniyeti

Etkileyen Faktörler

Şekil 3. Ölçeklere ilişskin faktörler

$\mathrm{Bu}$ çalışma kapsamında geliştirilen, geçerlik ve güvenirlik analizleri yapılan "e-Öğrenme Sürecine İlişkin Hazır Bulunuşluk ve Beklenti Ölçeği" ile "e-Öğrenme Sürecine İlişkin Memnuniyet Ölçeği"nin gelecekte bu konulara ilişkin yapılan çalışmalarda yol gösterici ve destekleyici olması beklenmektedir. e-Öğrenme sürecinde hazır bulunuşluk ve memnuniyet düzeylerinin hangi boyutlardan etkilendiği ve bu konuda neler yapılabileceği, geliştirilecek stratejiler, alınacak önlemler ve öngörülen müdahaleler açısından önemli rol oynamaktadır. e-Öğretimin kalitesini arttırmaya yönelik olarak incelenecek her değişken, sürecin kalitesini ve öğrenci başarısını arttırmak adına bilimsel açıdan büyük önem taşımaktadır. 


\section{KAYNAKLAR}

Aoki, K. (2010). The Use of ICT and e-Learning in Higher Education in Japan. World Academy of Science, Engineering \& Technology, 66, 868-872.

Barker, K. (2002). Canadian Recommended e-Learning Guidelines (CanREGs). FuturEd.

Beqiri, M. S., Chase, N. M. ve Bishka, A. (2009). Online Course Delivery: An Empirical Investigation of Factors Affecting Student Satisfaction. Journal Of Education For Business, 85(2), 95-100.

Bray, E., Aoki, K. ve Dlugosh, L. (2008). Predictors of Learning Satisfaction in Japanese Online Distance Learners. International Review Of Research In Open And Distance Learning, 9(3), 1-24.

Dada, D. (2006). E-Readiness for Developing Countries: Moving the Focus from the Environment to the Users. The Electronic Journal on Information Systems in Developing Countries, 27(6), 1-14.

Darab, B. ve Montazer, G. A. (2011). An eclectic model for assessing e-learning readiness in the Iranian universities. Computers \& Education, 56(3), 900-910.

Economist Intelligence Unit. (2009). e-Readiness Rankings 2009: The Usage Imperative. Raising. 28.1.2012 tarihinde http:/graphics.eiu.com/pdf/Ereadiness\%20rankings.pdf adresinden ulaşılmıştır.

GeoSINC International (2002). e-Readiness Guide. How to Develop and Implement a National e-Readiness Action Plan in Developing Countries. Washington, DC: infoDev - The World Bank. 28.1.2012 tarihinde http://www.apdip.net/documents/evaluation/e-readiness/geosinc01042002.pdf adresinden ulaşılmıştır.

Ilgaz, H. (2008). Uzaktan Eğitimde Teknoloji Kabulünün ve Topluluk Hissinin Öğrenen Memnuniyetine Katkısı. Yayımlanmamış Yüksek Lisans Tezi. Hacettepe Üniversitesi, Fen Bilimleri Enstitüsü, Ankara.

Hanafizadeh, P., Hanafizadeh, M. R. ve Khodabakhshi, M. (2009). Taxonomy of ereadiness assessment measures. International Journal of Information Management, 29(3), 189-195.

Hye-Jung, L. ve Rha, I. (2009). Influence of Structure and Interaction on Student Achievement and Satisfaction in Web-Based Distance Learning. Journal Of Educational Technology \& Society, 12(4), 372-382.

Jung-Wan, L. ve Mendlinger, S. (2011). Perceived Self-Efficacy and Its Effect on Online Learning Acceptance and Student Satisfaction. Journal Of Service Science \& Management, 4(3), 243-252.

Keramati, A., Afshari-Mofrad, M. ve Kamrani, A. (2011). The role of readiness factors in E-learning outcomes: An empirical study. Computers \& Education, 57(3), 1919-1929.

KING ICT. (2011). E-readiness report for e-learning implementation in Kosovo. EU IT Pilot Project in the Field of Education. 28.1.2012 tarihinde http://www.itpilotproject.eu/presentations/E-readiness-report-for-elearningimplementation-in-kosovo.pdf adresinden ulaşılmıştır. 
Machado, C. (2007). Developing an e-readiness model for higher education institutions: results of a focus group study. British Journal Of Educational Technology, 38(1), 72-82.

Naidu, S. (2006). E-Learning: A Guidebook of Principles, Procedures and Practices (2nd revised ed.). The Commonwealth Educational Media Centre for Asia. 28.1.2012 tarihinde http://www.cemca.org/e-learning_guidebook.pdf adresinden ulaşılmıştır.

Palmer, S. R. ve Holt, D. M. (2009). Examining student satisfaction with wholly online learning. Journal of Computer Assisted Learning, 25(2), 101-113.

Palmer, S. ve Holt, D. (2010). Students' perceptions of the value of the elements of an online learning environment: looking back in moving forward. Interactive Learning Environments, 18(2), 135-151.

Pena, M. ve Yeung, A. (2010). Satisfaction with Online Learning: Does Students' Computer Competence Matter?. International Journal Of Technology, Knowledge \& Society, 6(5), 97-108.

Shraim, K. ve Khlaif, Z. (2010). Students' Readiness Towards E-learning. A case study of Virtual Classrooms for secondary education in Palestine. The 3rd Annual Forum on e-learning Excellence in the Middle East. Dubai. 1-4 Feb 2010.

Stephen, M., Mutula, S. M. ve Brakel, P. (2006). An evaluation of e-readiness assessment tools with respect to information access: Towards an integrated information rich tool. International Journal of Information Management, 26, 212-223.

Sümer, N. (2000). Yapısal Eşitlik Modelleri: Temel Kavramlar ve Örnek Uygulamalar. Türk Psikoloji Yazıları, 3(6), 49-74.

Swedish National Agency for Higher Education. (2008). E-learning quality aspects and criteria for evaluation of e-learning in higher education. Report 2008:11 R. Stockholm: Högskoleverkets rapportserie. 28.1.2012 tarihinde http://www.hsv.se/download/18.8f0e4c9119e2b4a60c800028057/0811R.pdf adresinden ulaşılmıştır.

Tabachnick, B. G. Ve Fidell, L. S. (2001). Using multivariate statistics (4th ed.). Boston: Allyn and Bacon.

Watkins, R., Leigh, D. ve Triner, D. (2004). Assessing Readiness for E-Learning. Performance Improvement Quarterly, 17(4), 66-79.

Wright, C. R. (2003). Criteria for Evaluating the Quality of Online Courses. 28.1.2012 tarihinde http://elearning.typepad.com/ thelearnedman/ID/evaluatingcourses.pdf adresinden ulaşılmıştır.

Zawacki-Richter, O. (2009). Research Areas in Distance Education: A Delphi Study. International Review of Research in Open and Distance Learning, 10(3), 1-17. 
